\title{
Glossopharyngeal and vagus neuropathy associated to stylopharyngeus muscle compression in horse guttural pouch - case report
}

\section{Neuropatia do glossofaringeo e vago associada à compressão pelo musculo estilofaringeo em bolsa gutural de equino - relato de caso}

\author{
Juliana de Moura Alonso ${ }^{1}$; Carlos Alberto Hussni ${ }^{1}$; Marcos Jun Watanabe ${ }^{1}$; Ana Liz Garcia Alves ${ }^{1}$; \\ Marília Ferrari Marsiglia²; Celso Antônio Rodrigues ${ }^{2 *}$ (D)
}

\begin{abstract}
Neuropathies of pharyngeal branches of glossopharyngeal and vagus are often associated with guttural pouches diseases; however, these branches of injury due to stylopharyngeus muscle compression are not reported. A case was reported of a quarter horse mare, 8 years old, $450 \mathrm{~kg}$, presenting dyspnea and respiratory noise associated with weight loss. Clinical examination observed mixed dyspnea, tachycardia, dysphagia, sialorrhea, lung crackles and submandibular and parotid lymphadenopathy. Endoscopic exam showed right arytenoid chondritis, nasopharyngeal collapse, generalized larynx edema and dorsal displacement of the soft palate. Right guttural pouch evaluation showed swelling in the origin of stylopharyngeus muscle with consequent compression of the XII, X and IX cranial nerves. Tracheotomy, systemic treatment with corticosteroids, beta lactams and aminoglycosides antibiotics were performed. No resolution was observed and, after 16 days, the animal showed clinical worsening, developed pleuropneumonia, uveitis, severe sepsis, acute renal failure and was euthanized. The mixed neuropathy resulted in rapid clinical deterioration of the animal, due to the difficulty in swallowing and consequent associated respiratory processes. This report emphasizes the importance of evaluating stylopharyngeus muscle origin in cases of nasopharyngeal collapse associated with dysphagia in horses, given the possibility that structural changes in this muscle can result in laryngeal neuropathy.
\end{abstract}

Keywords: Dysphagia. Dyspnea. Equine. Nasopharyngeal collapse.

\section{RESUMO}

As neuropatias do glossofaríngeo e vago são frequentemente associadas com enfermidade das bolsas guturais. A ocorrência desta lesão secundária a compressão pelo músculo estilofaríngeo não é reportada. Relata-se o caso de uma égua quarto de milha, 8 anos de idade, $450 \mathrm{~kg}$, apresentando dispneia, ruído respiratório e perda de peso. No exame clínico observou-se dispnéia mista, taquicardia, disfagia, sialorréia, crepitação pulmonar e linfadenopatia submandibular e parotídea. Ao exame endoscópico identificou-se condrite aritenóide direita, colapso nasofaríngeo, edema generalizado da laringe e deslocamento dorsal do palato mole. Na avaliação da bolsa gutural direita identificou-se aumento de volume na origem do músculo estilofaríngeo com consequente compressão dos nervos cranianos XII, X e IX. Foi realizada traqueotomia, tratamento sistêmico com corticosteróides e antibióticos. Nenhuma resolução foi observada, após 16 dias o animal apresentou piora clínica, pleuropneumonia, uveíte, sepse grave, insuficiência renal aguda e foi submetido à eutanásia. A neuropatia mista resultou em rápida deterioração clínica do animal, devido à dificuldade de deglutição e processos respiratórios associados. Salienta-se a importância de se avaliar a origem do músculo estilofaríngeo em casos de colapso nasofaríngeo associado a disfagia em cavalos, dada a possibilidade de que alterações estruturais nesse músculo possam resultar em neuropatia laríngea.

Palavras chave: Disfagia. Dispneia. Cavalo. Colapso da nasofaringe. 
Correspondence to:

Celso Antônio Rodrigues

Rua Prof. Doutor Walter Mauricio Correa, s/n - Universidade Estadual Paulista "Júlio de Mesquita Filho", Campus de Botucatu CEP: 18618-681, Botucatu - SP, Brazil

e-mail: rodriguesca@fmvz.unesp.br

Submited: May 28, 2018

Approved: December 18, 2018

How to cite: Alonso JM, Hussni CA, Watanabe MJ, Alves ALG, Marsiglia MF, Rodrigues CA. Glossopharyngeal and vagus neuropathy associated to stylopharyngeus muscle compression in horse guttural pouch - case report. Braz J Vet Res Anim Sci. 2019;56(1):e146549. https://doi. org/10.11606/issn.1678-4456.bjvras.2019.146549

\section{Introduction}

The stylopharyngeus muscle originates in the axial aspect of stylohyoid bone, is directed ventrally and inserted in the dorsal wall of the nasopharynx. In swallowing, its contraction dorsally shifts the nasopharynx to receive the bolus; in breathing, it supports the nasopharynx, preventing the collapse (Kuna \& Vanoye, 1999; Holcombe \& Ducharme, 2008)

Neuropathies of glossopharyngeal and vagus pharyngeal branches are often associated with diseases that affect the guttural pouches (Borges \& Watanabe, 2011) and / or retropharyngeal lymphadenopathy, causing compression on the pharyngeal nerve plexus (Ducharme, 2006).

The increased volume at the stylopharyngeus muscle origin associated with its dysfunction and neuropathy development has not been previously reported. This report aims to describe the occurrence of glossopharyngeal and vagus pharyngeal branches neuropathy associated with dysfunction and increased volume in stylopharyngeus origin muscle with development of nasopharyngeal collapse and dysphagia.

\section{Casuistry}

A quarter horse mare, 8 years old, $450 \mathrm{~kg}$ of body weight was received with sudden appearance of dyspnea and respiratory noise one month prior associated with the loss of approximately $150 \mathrm{~kg}$ body mass in this time interval. The owner reported a previous endoscopic examination by a veterinarian, where arytenoid chondritis was diagnosed and the animal referred to the veterinary hospital. In the clinical examination at admission, the animal showed mixed dyspnea, tachycardia, tachypnea, dysphagia, sialorrhea, extension of the neck, thin pulmonary crackles in cranial lobes and submandibular and parotid lymphadenopathy.

Due to the inconsistency of clinical signs with the diagnosis of arytenoid chondritis, we performed a new videoendoscopic examination, which revealed the presence of a granulomatous mass in the transition of the arytenoid body and its corniculate process, featuring right arytenoid chondritis with cartilage paralysis. There was also the presence of nasopharyngeal collapse, generalized edema of the larynx and dorsal displacement of the soft palate (DDSP). The right guttural pouch evaluation showed swelling in the origin of stylopharyngeus muscle compressing the XII, X and IX cranial nerves in the medial compartment of the guttural pouch (Fig. 1). The left guttural pouch revealed a normal stylopharyngeus muscle without evidence of contact and / or compression of the cranial nerves.

Blood count analysis showed normal leukocytes ( $\left.13.6 \times 10^{3} / \mathrm{microl}\right)$ with neutrophilia $\left(12 \times 10^{3} / \mathrm{microl}\right)$, monocytosis $\left(1 \times 10^{3} / \mathrm{microl}\right)$ and lymphopenia $\left(0.6 \times 10^{3} / \mathrm{microl}\right)$. Structural radiographic changes were not detected in guttural pouches; however, there was a slight asymmetry between the right and left. Due to the degree of dyspnea, collapse of the pharynx and intense laryngeal edema presented, we initially opted for a temporary tracheotomy and systemic daily treatment with dexamethasone $(0.5 \mathrm{mg} / \mathrm{kg}$ IV SID for 3 days following with $0.05 \mathrm{mg} / \mathrm{kg}$ IV until the seventh day of treatment) and daily antibiotic: gentamicin ( $6.6 \mathrm{mg} / \mathrm{kg} \mathrm{IV})$; ceftriaxone ( $25 \mathrm{mg} / \mathrm{kg}$ IV every $12 \mathrm{~h}$ ), both for 15 days. The animals also received daily omeprazole ( $2 \mathrm{mg} / \mathrm{kg}$ PO 15 days), clenbuterol every $12 \mathrm{~h}$ ( $0.8 \mathrm{mcg} / \mathrm{kg}$ po 7 days $)$, daily bromhexine hydrochloride ( $0.3 \mathrm{mg} / \mathrm{kg}$, IV, 7 days). Local infusion of a solution with saline, dexamethasone and DMSO was topically administered by nasal tube.

After 1 week of treatment, the animal showed endoscopic reduction of larynx edema (Fig. 1-C), maintenance of DDSP and guttural pouch changes. Dysphagia and progressive weight loss was also present. After 16 days, the animal showed clinical worsening with intense purulent tracheal secretions through tracheotomy, silence areas and increased lung crackles. Pulmonary sonographic examination found severe diffuse pleuropneumonia, with pulmonary consolidation areas and mild pleural effusion. Fibrinogen was increased (600 mg / dL), leukopenia (2.2 x $103 / \mathrm{uL}$ ) with neutropenia $(1.2 \times 103 / \mathrm{uL})$ and lymphopenia $(0.7 \times 103 / \mathrm{uL})$ was observed. Due to treatment resistance, clinical signs of severe sepsis with hyperthermia, dehydration, endotoxemia, acute renal failure (urea 99.6 and creatinine $4.55 \mathrm{mg} / \mathrm{dL}$ ) and acute pyogenic uveitis, the animal was euthanized. 

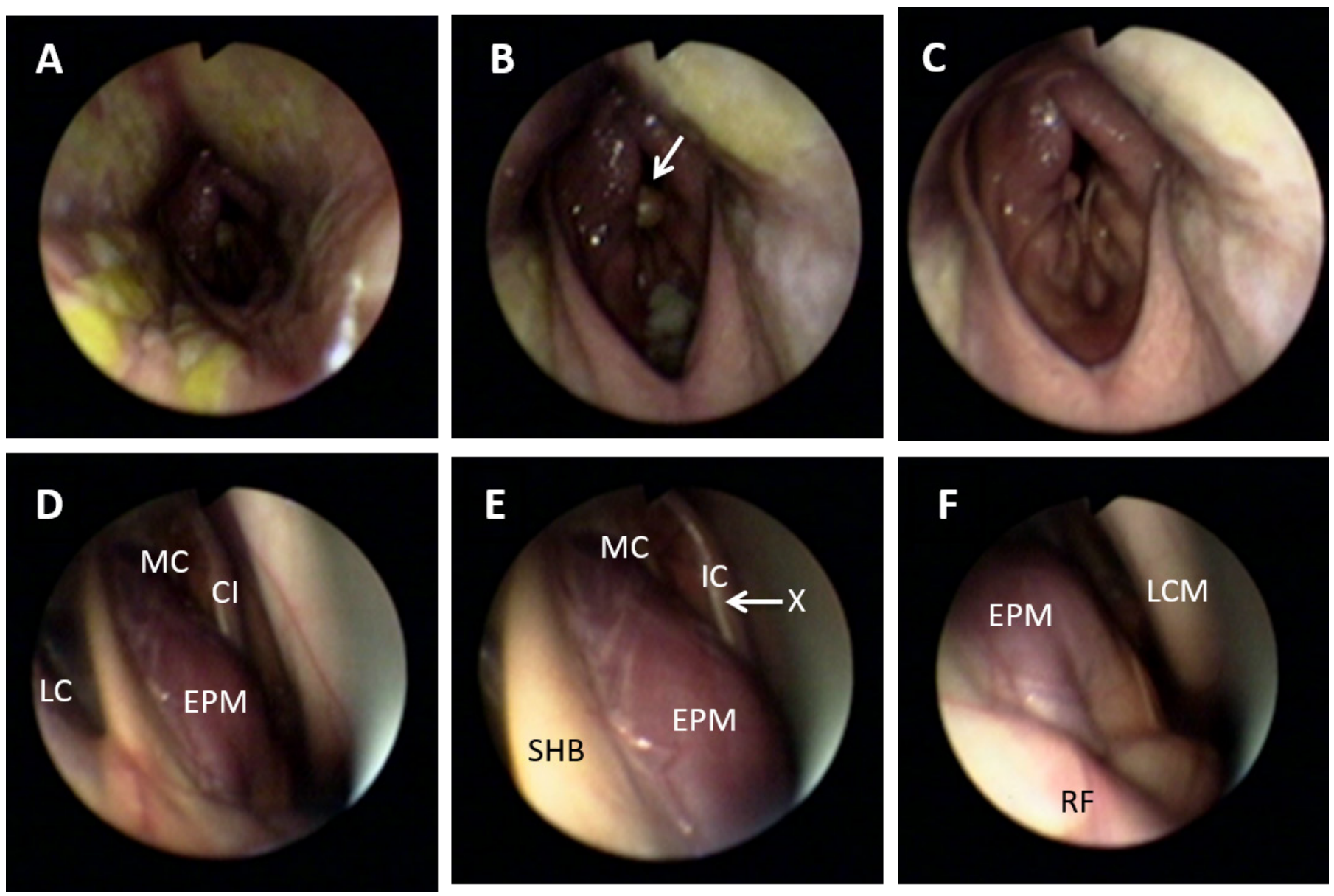

Figure 1 -A- Nasopharynx on admission: nasopharynx collapse (dorsal, ventral and lateral wall), presence of diffuse fibrin; B- Larynx on admission: Arrow points to the arytenoid chondritis with paralysis of the right arytenoid, presence of diffuse edema, DDSP, and shows nasopharyngeal roof partially running down and covering the left arytenoid cartilage; C- Larynx after 7 days of treatment: absence of fibrin, persistence of DDSP, decreased edema and arytenoid chondritis maintaining the right laryngeal paralysis; D- Right guttural pouch: MC (medial compartment), LC (lateral compartment), IC (internal carotid), SPM (stylopharyngeus muscle); E-Approximate view of the right guttural pouch: MC, IC, vagus nerve (X), SPM, SHB (Stylohyoid bone), increased volume in SPM prevents the display of the cranial nerves (IX glossopharyngeal and hypoglossal XII); F- Ventral aspect of the right guttural pouch: LCM (longus capitis muscle), retropharyngeal lymph node region (RF), SPM, SPM increased volume prevents the display of the vagus nerve (X).

\section{Discussion and Conclusion}

Nasopharynx collapse has been seen as a potential cause of exercise intolerance and respiratory noise in horses (Kannegieter \& Dore, 1995; Tessier et al., 2004). However, despite that the anatomy and physiology of the nasopharyngeal region are fully described (Sisson, 1976; Kuna \& Vanoye, 1997; Feroah et al., 2000; Kuna, 2001; Holcombe \& Ducharme, 2008), only recently has the importance of stylopharyngeus muscle in support of the nasopharynx and its close relationship with the occurrence of the disease (Tessier et al., 2004) been reported.

The stylopharyngeus muscle is innervated by the pharyngeal branch of the glossopharyngeal nerve. The clinical symptoms presented, with the combination of the collapse of the nasopharynx, dysphagia and DDSP suggests the occurrence of mixed neuropathy, possibly a lesion located in the pharyngeal plexus, which resulted in injury to both to the glossopharyngeal nerve pharyngeal branch as the pharyngeal and laryngeal recurrent branches of the vagus nerve. It should also be noted that all the pharyngeal muscles except the stylopharyngeus are innervated by the vagus nerve, and the larynx muscles are innervated by the recurrent laryngeal branch of the vagus nerve (Borges \& Watanabe, 2011).

The occurrence of vagus nerve damage can result in dysphagia and inspiratory dyspnea due to paralysis of the larynx and DDSP (Borges \& Watanabe, 2011). The occurrence of PMDD associated with pharyngeal collapse as described in this report was previously described by Parente et al. (Parente et al., 2002), who reported that among 92 horses diagnosed with DDSP at dynamic endoscopic exam, 11 had associated pharyngeal collapse.

Although stylopharyngeus muscle dysfunction has been previously reported (Tessier et al., 2004; Holcombe 
\& Ducharme, 2008), the association of its dysfunction occurrence with dysphagia was not previously described. After bilateral locking of glossopharyngeal nerve in horses (Tessier et al., 2004) and dogs (Haagen et al., 1986), it was demonstrated that the occurrence of nasopharynx collapse not accompanied by dysphagia. Possibly, the presented dysphagia in this case was the result of glossopharyngeal and vagus nerve compression in pharyngeal plexus area. However, despite the endoscopic examination suggesting that the etiology of this compression is associated with the presence of swelling in stylopharyngeus muscle origin, it is not clear what triggered the increase in volume found.

The occurrence of local trauma in the guttural pouch region and retropharyngeal lymphadenopathy can reportedly trigger inflammation by contiguity of the pharyngeal branch of the vagus nerve (Ducharme, 2006). The presence of swelling in the submandibular and parotid lymph nodes suggests that the hypothesis of prior sensitization by infectious agent with consequent retropharyngeal lymphadenopathy may have been responsible for the inflammation in neuropathy and swelling found in stylopharyngeus muscle.

The retropharyngeal lymphadenopathy occurs more often due to bacterial infection by Streptococcus equi or viral processes (herpesvirus, influenza, viral arteritis) (Waller et al., 2013). Although there are no reports from the owner about the occurrence of clinical signs associated with strangles or viral infections, it is suggested that this process may have triggered the observed change at the stylopharyngeus origin and consequent nerve compression muscle. In spite of the presence of sonographic reaction in retropharyngeal lymph and the slight radiographic asymmetry, no compression of guttural pouch was observed by lymph nodes on necropsy.

The arytenoid chondritis observed may be associated with the same infectious etiological agent that triggered neuropathy, since the occurrence of the disease is closely related to an infectious process (Sullins, 2002). The presence of arytenoid chondritis often results in paralysis of the arytenoid (Stick et al., 1999; Sullins, 2002); however, the paralysis observed could also be due to vagus nerve recurrent laryngeal branch neuropathy in the region of guttural pouch (Borges \& Watanabe, 2011).

Prolonged administration of corticosteroids associated with DMSO did not result in significant reduction of the local inflammatory response and may have triggered worsening of the infection.

The nasopharynx intrinsic muscles and its associated nerve branches act as important factors associated with the etiology of nasopharyngeal diseases. However, despite recent advances in the description of muscle and nerve function, there is a limitation in diagnostic techniques and description of the primary etiology of these diseases. The close relationship and proximity of laryngeal structures hindered the clarification of primary and secondary proceedings in this case.

The mixed neuropathy observed in this case resulted in rapid clinical deterioration of the animal, due to the resistance to treatment, difficulty swallowing food and consequent associated respiratory injuries. The prognosis of pharyngeal collapse is bad for sports activity (Kannegieter \& Dore, 1995) and, when associated with the vagus neuropathy, results in worsening not only athletic activity, but also quality of life of patients.

Evaluating the origin of stylopharyngeus muscle in cases of nasopharyngeal collapse associated with dysphagia in horses is emphasized, as structural changes can result in compression and neuropathy.

\section{Conflict of Interests}

The authors declare that there is no conflict of interest regarding the publication of this paper.

\section{Ethics Statement}

A consent to publish the case is signed at admission by the owner/legal guardian.

\section{References}

Borges AS, Watanabe MJ. Guttural pouch diseases causing neurologic dysfunction in the horse. Vet Clin North Am Equine Pract. 2011;27(3):545-72. http://dx.doi.org/10.1016/j. cveq.2011.08.002. PMid:22100044.

Ducharme NG. Pharynx. In: Auer JA, Stick JA, editors. Equine surgery. Philadelphia: WB Saunders; 2006. http:// dx.doi.org/10.1016/B1-41-600123-9/50045-0.
Feroah TR, Forster HV, Pan LG, Rice T. Reciprocal activation of hypopharyngeal muscles and their effect on upper airway area. J Appl Physiol. 2000;88(2):61126. http://dx.doi.org/10.1152/jappl.2000.88.2.611. PMid:10658029.

Haagen AJVV, Hartman W, Wolvekamp WTC. Contributions of the glossopharyngeal nerve and the pharyngeal branch 
of the vagus nerve to the swallowing process in dogs. Am J Vet Res. 1986;47(6):1300-7. PMid:3729131.

Holcombe SJ, Ducharme NG. Upper airway function of normal horses during exercise. In: Hinchcliff WH, Geor RJ, Kaneps AJ, editors. Equine exercise physiology. 5th ed. Philadelphia: Saunders Elsevier; 2008. p. 170-92. http:// dx.doi.org/10.1016/B978-070202857-1.50010-X.

Kannegieter NJ, Dore ML. Endoscopy of the upper respiratory tract during treadmill exercise: a clinical study of 100 horses. Aust Vet J. 1995;72(3):101-7. http://dx.doi. org/10.1111/j.1751-0813.1995.tb15020.x. PMid:7611982.

Kuna ST, Vanoye CR. Mechanical effects of pharyngeal constrictor activation on pharyngeal airway function. J Appl Physiol. 1999;86(1):411-7. http://dx.doi.org/10.1152/ jappl.1999.86.1.411. PMid:9887155.

Kuna ST, Vanoye CR. Respiratory-related pharyngeal constrictor muscle activity in decerebrate cats. J Appl Physiol (1985). 1997;83(5):1588-94. http://dx.doi.org/10.1152/ jappl.1997.83.5.1588. PMid:9375324.

Kuna ST. Effects of pharyngeal muscle activation on airway size and configuration. Am J Respir Crit Care Med. 2001;164(7):1236-41. http://dx.doi.org/10.1164/ ajrccm.164.7.2011030. PMid:11673216.

Parente EJ, Martin BB, Tulleners EP, Ross MW. Dorsal displacement of the soft palate in 92 horses during highspeed treadmill examination (1993-1998). Vet Surg.
2002;31(6):507-12. http://dx.doi.org/10.1053/jvet.2002.36009. PMid:12415518.

Sisson S. The anatomy of domestic animals. Philadelphia: WB Saunders Co; 1976. Peripheral nervous system; p. 659-60.

Stick JA, Tulleners EP, Robertson JT. Larynx. In: Auer JA, Stick JA. Equine surgery. 2nd ed. Philadelphia: Saunders; 1999. p. 364-66.

Sullins KE. Minimally invasive laser treatment of arytenoid chondritis in horses. Clinical Techniques in Equine Practice. 2002;1(1):13-6. http://dx.doi.org/10.1053/ctep.2002.33176.

Tessier C, Holcombe SJ, Derksen FJ, Berney C, Boruta D. Effects of stylopharyngeus muscle dysfunction on the nasopharynx in exercising horses. Equine Vet J. 2004;36(4):318-23. http:// dx.doi.org/10.2746/0425164044890553. PMid:15163038.

Waller AS, Sellon DC, Sweeney CR, Timoney PJ, Newton JR, Hines MT. Streptococcal infections. In: Sellon DC, Long $\mathrm{M}$, editors. Equine infections disease. Englewood: Saunders; 2013. p. 265.

Financial support: Author declares this study has been exempt of financial support.

Authors Contributions: JMA, MFM e CAR were responsible for animal hospital care; JMA, MFM e CAH conceived text preparation; MJW, ALGA and CAR were responsible for review and approval of the text. 